\title{
一般口演 2
}

\section{運動論的顆頭点の検証}

\section{Verification of kinematic condylar point}

$\bigcirc$ 重本修伺 ${ }^{1)}$, 石川輝明 ${ }^{2)}$, 坂東永一 ${ }^{5)}$, 野口直人 ${ }^{1)}$, 鈴木善貴 ${ }^{1)}$, 福井真弓 ${ }^{1)}$, 大倉一夫 ${ }^{1)}$, 薩摩登誉子 ${ }^{1)}$, 山本修史 ${ }^{1)}$, 中野雅徳 ${ }^{3)}$, 西川啓介 ${ }^{4)}$, 竹内久裕 ${ }^{4)}$, 久保吉廣 ${ }^{4)}$

Shigemoto S. ${ }^{1)}$, Ishikawa T. ${ }^{2)}$, Bando E. ${ }^{5)}$, Noguchi N. ${ }^{1)}$, Suzuki Y. ${ }^{1)}$, Fukui M. ${ }^{1)}$, Okura K. ${ }^{1)}$, Satsuma T. ${ }^{4)}$, Yamamoto T. ${ }^{1)}$, Nakano M. ${ }^{3)}$, Nishigawa K. ${ }^{4)}$, Takeuchi H. $^{4)}$, Kubo Y. ${ }^{4)}$

徳島大学大学院ヘルスバイオサイエンス研究部 1) 咬合管理学分野, 2) 総合診療歯科学分野,

3) 口腔保健福祉学講座, ${ }^{4)}$ 徳島大学医学部・歯学部附属病院歯科, 5) 徳島大学

1) Department of Fixed Prosthodontics, ${ }^{2)}$ Department of Comprehensive Dentistry, ${ }^{3)}$ Department of Functional Oral Care and Welfare, Institute of Health Biosciences, The University of Tokushima Graduate School,

${ }^{4)}$ General Dentistry, Tokushima University Hospital, ${ }^{5)}$ The University of Tokushima

\section{I. 目 的}

下顎が運動できる空間すなわち下顎限界運動野は，切 歯点の運動については Posselt’s figure としてよく知られ ている. 切歯点より後方では運動野の上下幅は小さくな り，下顎頭の中央付近で最も収斂した形態となることを 鈴木が報告している ${ }^{1)}$. しかし, 鈴木の使用した顎運動 測定器 $\mathrm{MM}-\mathrm{JI}^{2)}$ は，上下顎の顔弓をメカニカルに連結し た構造を持ち, 下顎に約 $127 \mathrm{~g}$ の負荷がかかるものであ った．測定器のこのような特性が測定結果に影響を及ぼ すことはなかったのであろうかという疑問が生じる. そ こで顎運動測定器 MM-JI より生理的な条件で顎運動測 定を行うことができる磁気式測定器 $\mathrm{CS}-\mathrm{Iii}^{3)}$ を用いて検 証することとした.

\section{II. 方 法}

\section{1. 被験者}

被験者は, 顎口腔系の機能異常およびその既往がなく， 個性正常咬合を有する成人有歯顎者（男性 17 名, 女性 19 名 平均年齢 $25.9 \pm 4.6$ 歳）とした. なお, 本学臨床研 究倫理審査委員会の承認を得て, 事前に実験の趣旨を被 験者に十分に説明し，同意を得た上で実験を行った.

\section{2. 顎運動測定}

被験者を歯科用チェアに安静な状態で座らせ石川らが

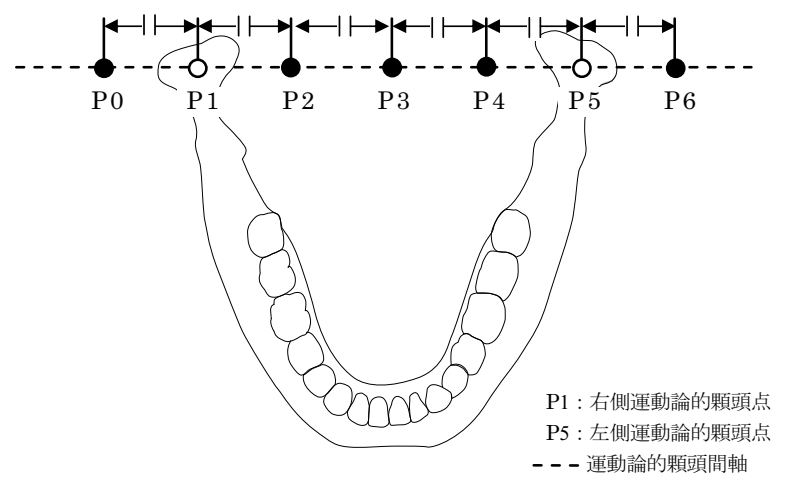

図1. 解析対象点

開発したCS-IIi を用いてサンプリング周波数 $100 \mathrm{~Hz}$ で 測定した.

\section{3. 解析対象点}

矢状面内限界運動, 左側方限界運動, 右側方限界運動 の経路から鈴木 ${ }^{1)}$ の方法に準じて運動論的顆頭点を求め た. 左右運動論的顆頭点を結ぶ顆頭閒軸上の 7 点を解析 対象点（P0-P6）とした（図 1).

1）運動経路の厚みと幅

解析対象点における矢状面内限界運動の矢状面投影に 対して最小自乗法円近似を行い，近似円を求める。この 近似円の円周を $0.2 \mathrm{~mm}$ に分割する範囲毎に矢状面内限 界運動と左右側方限界運動経路の半径方向の厚みと水平 方向の幅を求め, 全運動経路のそれぞれの最大值を解析 対象点の運動経路の厚みと幅とした. 

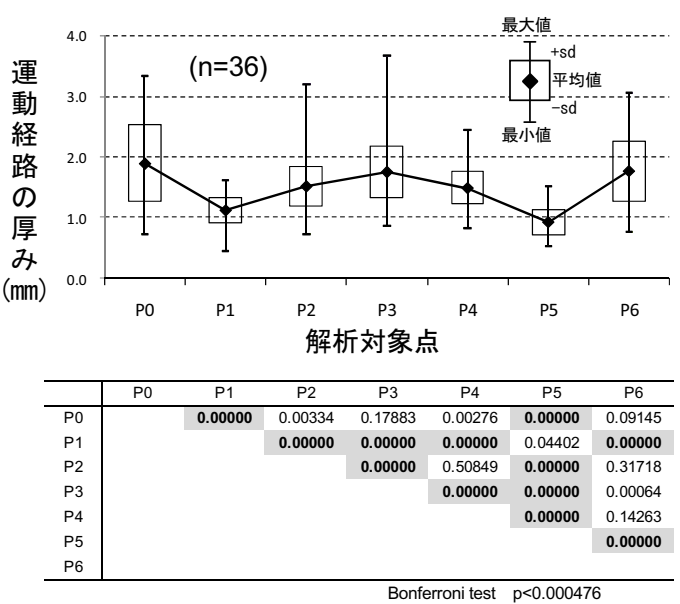

図 2. 解析対象点の運動経路の厚み

\section{4. 検定方法}

解析対象点の顆路の厚みと幅についてボンフェローニ 法を用いて各群間の多重比較を行った。また鈴木 ${ }^{1)}$ の報 告した男性被験者 10 名（MM-JI 群）と今回の男性被験 者 17 名（CS-IIi 群）の運動論的顆頭点顆路の厚みと運動 論的顆頭間距離の $\mathrm{t}$-検定を用いて群間比較を行った.

\section{III. 結果·考察}

解析対象点の顆路の厚みと幅について各群間の多重比 較を行った結果, 左右運動論的顆頭点（P1，P5）の顆路 の幅は他の解析対象点に対して有意な差は認められなか ったが, 顆路の厚みは有意に小さく（図 2), 鈴木の報告 と同様に顆頭間軸上の点の中で運動論的顆頭点は運動範 囲が最も収斂していた. 36 名の運動論的顆頭点顆路の幅 は $0.98 \pm 0.25 \mathrm{~mm}$ であった. 同様に解析対象点の矢状面内 限界運動経路の厚みを比較した結果, 左右の運動論的顆 頭点は運動経路が最も収斂する点ではなかった（図 3)

左右側方限界運動を解析に含めることで運動論的に左 右顆頭参照点を求めることが可能であることが示され た. 運動論的顆頭点は, 下顎運動のモデル化を通して下 顎運動を理解したり, 咬合器を作製して患者の顎運動を 再現するときに非常に重要な参照点となることが再確認 できた。

CS-IIi 群は MM-JI 群に対して運動論的顆頭点の顆路の 厚みが有意に大きく, また運動論的顆頭間距離が有意に 短い結果となった（図 4,5)。両研究の被験者やデータ 処理の手法が同一ではないため単純に比較できないが, 測定結果には，測定器の特性が僅かであるが影響を及ぼ している可能性があると考えられる.
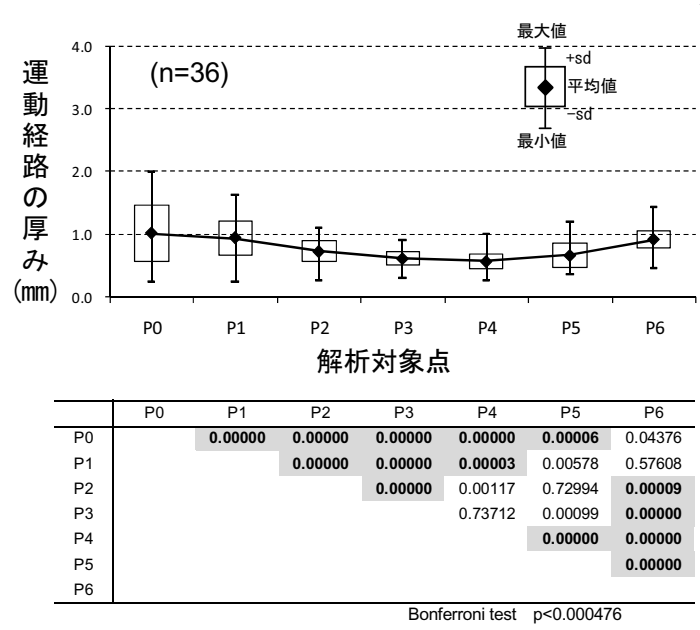

図 3. 解析対象点の運動経路の厚み

（矢状面内限界運動経路のみ）

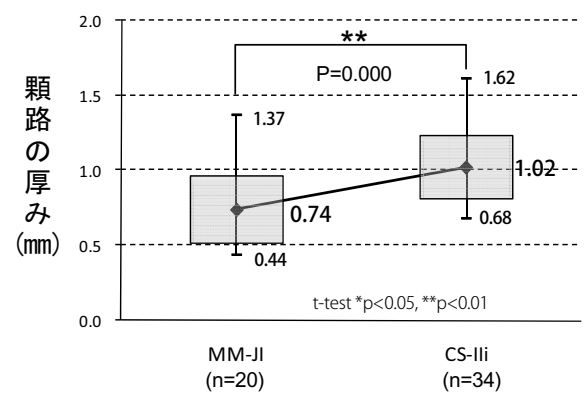

図 4. 運動論的顆頭点の顆路の厚み

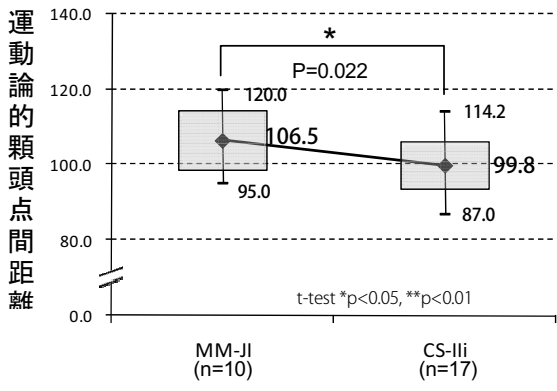

図 5. 運動論的顆頭点間距離

\section{IV. 文 献}

1）鈴木 温. ディジタル方式下顎運動測定器による下 顎限界運動の 6 自由度解析. 補綴誌 $1987 ; 31(3)$ ： 721-725.

2）坂東永一ほか. ディジタル方式による下顎運動測定. 顎機能 $1984 ; 2: 137-143$.

3）石川輝明. 三軸コイルを用いたチェアサイド用 6 自 由度顎運動測定器の開発と応用. 四国歯誌 2006 ; 19 : 55-66. 